\title{
Editorial
}

\section{Enhancing the Quality of Care in Long-Term Care Settings}

\author{
Reena Devi ${ }^{1,2, *}$, Adam Gordon ${ }^{3,4}$ (D) and Tom Dening ${ }^{3}$ (D) \\ 1 School of Healthcare, University of Leeds, Leeds LS2 9JT, UK \\ 2 Nurturing Innovation in Care Home Excellence in Leeds (NICHE-Leeds), Leeds, UK \\ 3 School of Medicine, University of Nottingham, Nottingham NG7 2RD, UK; \\ Adam.Gordon@nottingham.ac.uk (A.G.); tom.dening@nottingham.ac.uk (T.D.) \\ 4 National Institute of Health Research (NIHR) Applied Research Collaboration-East Midlands (ARC-EM), \\ Nottingham, UK \\ * Correspondence: r.devi@leeds.ac.uk
}

\section{check for}

updates

Citation: Devi, R.; Gordon, A.; Dening, T. Enhancing the Quality of Care in Long-Term Care Settings. Int. J. Environ. Res. Public Health 2022, 19, 1409. https://doi.org/10.3390/ ijerph19031409

Received: 21 January 2022

Accepted: 24 January 2022

Published: 27 January 2022

Publisher's Note: MDPI stays neutral with regard to jurisdictional claims in published maps and institutional affiliations.

Copyright: (C) 2022 by the authors. Licensee MDPI, Basel, Switzerland. This article is an open access article distributed under the terms and conditions of the Creative Commons Attribution (CC BY) license (https:// creativecommons.org/licenses/by/ $4.0 /)$.
The quality of care in long-term care settings is a concern felt across the world given the growing number of dependent older people [1]; a population whose health and care needs are increasing over time [2]. This Special Issue set out to attract research focused around enhancing the quality of care in this setting. Since 2019, we have received articles at a regular pace and this Special Issue offers a collection of 22 manuscripts focused on a wide variety of topics. This Special Issue will now close, and in this closing editorial we summarise the content and share our thoughts on future research in this area.

Research included took place around the world (UK, Australia, Taiwan, The Netherlands, Belgium, Korea, USA, Spain, Brazil, Germany, and Italy), used a range of methods, and examined quality of care from different angles. Five papers focused on workforce, adding important evidence around supporting staff with training [3], the influences on job competency, satisfaction, and intention to stay in work [4,5], staff burnout [6], and the relationship between staff and organisation with quality of care [7]. Evidence aimed at teams who work with the sector to improve quality of care was also included. One paper presented a tool containing questions designed to help initiate conversations between innovators and care home staff [8], and another paper outlined essential learning directed at teams applying a Quality Improvement Collaborative tool in this context [9]. This Special Issue also comprises intervention studies, with interventions aimed at addressing depressive symptoms in nursing home residents [10,11], adjustment for new residents [12], social and psychological support [13], and loneliness and isolation [14]. Other studies present evidence which developed and tested quality indicators $[15,16]$, and tools which capture the experience of quality from a resident's perspective $[17,18]$, and assess partnership working between staff and families [19]. We also included studies that investigated factors associated with older people's experiences, such as the association between length of stay and end of life care [20], dry eyes or ocular lubricants with medication use, dementia, frailty and dry eyes [21], resident characteristics and their palliative care service use and comfort in the last week of life [22] and causes of infection-related hospitalizations [23]. Finally, the issue also includes a systematic review describing the current evidence base of care home research conducted in Brazil [24].

The articles published in this Special Issue on enhancing care in long term care offer an array of insights, contributions and perspectives from different angles. This highlights that enhancing quality is a complex issue, one that requires relevant stakeholders to take into consideration different types of knowledge. For example, there is a need to understand causes and associations of poor and good quality, the needs of the workforce, effective interventions that have undergone robust testing, and tools which can help to effectively guide implementing evidence into practice and measure the effectiveness of change. As editors of this Special Issue, we would have liked to see more evidence uncovering how to stimulate and sustain change in care home practice. From our experience of working in this 
area, care homes within their day to day "business as usual" activities have made progress with initiating changes. This activity though is rarely captured in the academic literature. We suggest that future researchers bring to the centre stage evidence around the specific processes and organisational structures that help care homes to successfully initiate and sustain improved outcomes in this setting.

We are pleased to offer interesting papers from across the world in this important field and bring them together in this way. The regular pace at which we received submissions to this Special Issue indicates significant interest and relevance of the issue. We hope that readers will both enjoy and use these findings in their own research and practice.

Author Contributions: All authors played a key role in editing this special issue. R.D. wrote a first draft of this closing editorial, and T.D. and A.G. reviewed and edited the editorial. All authors have read and agreed to the published version of the manuscript.

Funding: This research received no external funding. Reena Devi is a Linking Pin researcher part funded by Nurturing Innovation in Care Home Excellence in Leeds (NICHE-Leeds) initiative (https:/ / niche.leeds.ac.uk/). A.G. is funded in part by the NIHR Applied Research CollaborationEast Midlands (ARC-EM). The views expressed are those of the authors and not necessarily those of the NHS, the NIHR or the Department of Health and Social Care.

Conflicts of Interest: The authors declare no conflict of interest.

\section{References}

1. Kingston, A.; Comas-Herrera, A.; Jagger, C. Forecasting the care needs of the older population in England over the next 20 years: Estimates from the Population Ageing and Care Simulation (PACSim) modelling study. Lancet Public Health 2018, 3, e447-e455. [CrossRef]

2. Barker, R.O.; Hanratty, B.; Kingston, A.; Ramsay, S.E.; Matthews, F.E. Changes in health and functioning of care home residents over two decades: What can we learn from population-based studies? Age Ageing 2021, 50, 921-927. [CrossRef] [PubMed]

3. Aicken, C.; Hodgson, L.; de Vries, K.; Wilkinson, I.; Aldridge, Z.; Galvin, K. 'This Adds Another Perspective': Qualitative Descriptive Study Evaluating Simulation-Based Training for Health Care Assistants, to Enhance the Quality of Care in Nursing Homes. Int. J. Environ. Res. Public Health 2021, 18, 3995. [CrossRef] [PubMed]

4. $\quad$ Chang, Y.-C.; Yeh, T.-F.; Lai, I.-J.; Yang, C.-C. Job Competency and Intention to Stay among Nursing Assistants: The Mediating Effects of Intrinsic and Extrinsic Job Satisfaction. Int. J. Environ. Res. Public Health 2021, 18, 6436. [CrossRef]

5. $\quad$ Cheng, T.-J.; Hsu, Y.-M.; Tsai, T.-H.; Chen, M.-Y.; Tsay, S.-F.; Shieh, S.-H. Factors Affecting the Competence of Nursing Assistants in Taiwan Long-Term Care Institutions. Int. J. Environ. Res. Public Health 2020, 17, 9413. [CrossRef]

6. Kim, B.J.; Lee, S.-Y. A Cross-Sectional Study on the Impacts of Perceived Job Value, Job Maintenance, and Social Support on Burnout Among Long-Term Care Staff in Hawaii. Int. J. Environ. Res. Public Health 2021, 18, 476. [CrossRef]

7. López, J.; Pérez-Rojo, G.; Noriega, C.; Velasco, C. Personal and Work-Related Factors Associated with Good Care for Institutionalized Older Adults. Int. J. Environ. Res. Public Health 2021, 18, 820. [CrossRef]

8. Bunn, F.; Goodman, C.; Corazzini, K.; Sharpe, R.; Handley, M.; Lynch, J.; Meyer, J.; Dening, T.; Gordon, A.L. Setting Priorities to Inform Assessment of Care Homes' Readiness to Participate in Healthcare Innovation: A Systematic Mapping Review and Consensus Process. Int. J. Environ. Res. Public Health 2020, 17, 987. [CrossRef]

9. Devi, R.; Martin, G.; Banerjee, J.; Butler, L.; Pattison, T.; Cruickshank, L.; Maries-Tillott, C.; Wilson, T.; Damery, S.; Meyer, J.; et al. Improving the Quality of Care in Care Homes Using the Quality Improvement Collaborative Approach: Lessons Learnt from Six Projects Conducted in the UK and The Netherlands. Int. J. Environ. Res. Public Health 2020, 17, 7601. [CrossRef]

10. van Venrooij, I.; Spijker, J.; Westerhof, G.J.; Leontjevas, R.; Gerritsen, D.L. Applying intervention mapping to improve the applicability of precious memories, an intervention for depressive symptoms in nursing home residents. Int. J. Environ. Res. Public Health 2019, 16, 5163. [CrossRef]

11. Zirves, M.; Pfaff, H. Nursing Home Residents Aged over 80-A Cross-Sectional Analysis on Which Activity Traits Correlate to Positive Affect. Int. J. Environ. Res. Public Health 2020, 17, 9583. [CrossRef]

12. Saint-Bryant, C.A.; Murrill, J.; Hayward, J.K.; Nunez, K.-M.; Spector, A. SettleIN: Using a Manualised Intervention to Facilitate the Adjustment of Older Adults with Dementia Following Placement into Residential Care. Int. J. Environ. Res. Public Health 2020, 17, 2606. [CrossRef]

13. Latham, I.; Brooker, D.; Bray, J.; Jacobson-Wright, N.; Frost, F. The Impact of Implementing a Namaste Care Intervention in UK Care Homes for People Living with Advanced Dementia, Staff and Families. Int. J. Environ. Res. Public Health 2020, 17, 6004. [CrossRef]

14. Casey, D.; Barrett, E.; Kovacic, T.; Sancarlo, D.; Ricciardi, F.; Murphy, K.; Koumpis, A.; Santorelli, A.; Gallagher, N.; Whelan, S. The Perceptions of People with Dementia and Key Stakeholders Regarding the Use and Impact of the Social Robot MARIO. Int. J. Environ. Res. Public Health 2020, 17, 8621. [CrossRef] 
15. Dupont, C.; De Schreye, R.; Cohen, J.; De Ridder, M.; Block, L.V.D.; Deliens, L.; Leemans, K. Pilot Study to Develop and Test Palliative Care Quality Indicators for Nursing Homes. Int. J. Environ. Res. Public Health 2021, 18, 829. [CrossRef]

16. Favez, L.; Zúñiga, F.; Sharma, N.; Blatter, C.; Simon, M. Assessing Nursing Homes Quality Indicators' Between-Provider Variability and Reliability: A Cross-Sectional Study Using ICCs and Rankability. Int. J. Environ. Res. Public Health 2020, 17, 9249. [CrossRef]

17. Sion, K.; Verbeek, H.; Aarts, S.; Zwakhalen, S.; Odekerken-Schröder, G.; Schols, J.; Hamers, J. The Validity of Connecting Conversations: A Narrative Method to Assess Experienced Quality of Care in Nursing Homes from the Resident's Perspective. Int. J. Environ. Res. Public Health 2020, 17, 5100. [CrossRef]

18. Sion, K.; Verbeek, H.; De Vries, E.; Zwakhalen, S.; Odekerken-Schröder, G.; Schols, J.; Hamers, J. The Feasibility of Connecting Conversations: A Narrative Method to Assess Experienced Quality of Care in Nursing Homes from the Resident's Perspective. Int. J. Environ. Res. Public Health 2020, 17, 5118. [CrossRef]

19. Jang, H.-Y.; Song, E.-O. Development and Validation of the Scale for Partnership in Care-for Family (SPIC-F). Int. J. Environ. Res. Public Health 2020, 17, 1882. [CrossRef]

20. Collingridge Moore, D.; Payne, S.; Keegan, T.; Deliens, L.; Smets, T.; Gambassi, G.; Kylänen, M.; Kijowska, V.; OnwuteakaPhilipsen, B.; Van den Block, L. Associations between Length of Stay in Long Term Care Facilities and End of Life Care. Analysis of the PACE Cross-Sectional Study. Int. J. Environ. Res. Public Health 2020, 17, 2742. [CrossRef]

21. Aljeaidi, M.; Keen, C.; Bell, J.S.; Cooper, T.; Robson, L.; Tan, E.C.K. Dry Eyes, Ocular Lubricants, and Use of Systemic Medications Known or Suspected to Cause Dry Eyes in Residents of Aged Care Services. Int. J. Environ. Res. Public Health 2020, $17,5349$. [CrossRef]

22. Miranda, R.; Smets, T.; Noortgate, N.V.D.; Deliens, L.; Block, L.V.D. Higher Prevalence of Dementia but No Change in Total Comfort While Dying among Nursing Home Residents with Dementia between 2010 and 2015: Results from Two Retrospective Epidemiological Studies. Int. J. Environ. Res. Public Health 2021, 18, 2160. [CrossRef]

23. Sluggett, J.K.; Lalic, S.; Hosking, S.M.; Ritchie, B.; McLoughlin, J.; Shortt, T.; Robson, L.; Cooper, T.; Cairns, K.A.; Ilomäki, J.; et al. Root Cause Analysis to Identify Medication and Non-Medication Strategies to Prevent Infection-Related Hospitalizations from Australian Residential Aged Care Services. Int. J. Environ. Res. Public Health 2020, 17, 3282. [CrossRef]

24. Wachholz, P.; De Oliveira, D.; Hinsliff-Smith, K.; Devi, R.; Boas, P.V.; Shepherd, V.; Jacinto, A.; Watanabe, H.; Gordon, A.; Ricci, N. Mapping Research Conducted on Long-Term Care Facilities for Older People in Brazil: A Scoping Review. Int. J. Environ. Res. Public Health 2021, 18, 1522. [CrossRef] 